\title{
Transformative joy in Qohelet: A thread that faintly glistens
}

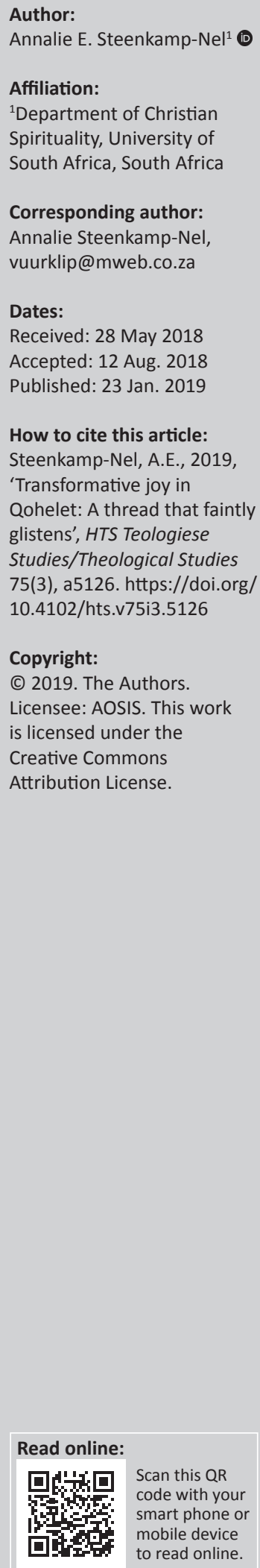

Qohelet prompted a rich body of work reflecting the breadth of the Old Testament book's appeal. Few, however, interpret Qohelet's spiritual dimension, incarnated in life. I will opt to offer an overarching framework that holds the book together and that was until now absent in the discourse on Qohelet. It will be argued that spiritual transformation provides a fruitful theoretical framework for Qohelet. I will indicate that Qohelet undertook a spiritual journey in which his experiences fostered profound spiritual transformation, and ultimately a new paradigm leapfrogging old spiritual infrastructure and choices. The framework that evolved from this effort delineates four phases, stages or movements. In order to provide clarity and enhance understanding of this concept, the analysis will be done on the basis of the leitwort (or keyword) 'joy'. The findings point to the importance of spiritual transformation, directing readers towards a new spirituality. The article concludes with suggestions on future directions regarding Qohelet as a 'bridge book' to the New Testament.

\section{Introduction}

This article studies the relation between spiritual transformation and joy in Qohelet. The purpose is to offer an all-encompassing theoretical framework that holds the book together and that was until now absent in the discourse on Qohelet. The very name, Qohelet, even amongst those who darken the doors of the church on Sunday mornings, ${ }^{1}$ is held in opprobrium or abeyance like the great pessimist, Dante's 'cammin de nostra vita' (1350:c.1r. canto 1-3), Henry James's labyrinthine and claustrophic 'Golden bowl' (James 1904), and in the African novelist's Achebe's intricate slow-burned 'Arrow of God' (1964:169). Although Qohelet pitched his tent seemingly on the outskirts of acceptability, it is not on the sideline anymore. The book intrigued an increasing number of scholars and spurred a rich body of work that reflects the breadth of Qohelet's appeal. It enjoys the thematic attention of movie literature (Johnston 2004), self-actualisation (Marcus 2003:6), bibliometrics (Harsanyi \& Harter 1993), rock albums (Army of Bones 2017; Helsel 2007) and a stage-adapted novel (Keiter 2015). A plethora of approaches and theoretical perspectives pondered on the implication of Qohelet for economics (Redding 2013), philosophy (Douglas 2011; Liston 1996), psychology (Cooper, Quick \& Shabraqc 2015:2), legality of technological data (Tene \& Polonetsky 2013:254), social work (Sneed 2012), communications (Morgan 2011), beer production (Homan 2002), health (Soliman, Sturgeon \& Hargest 2015; Thompson, Lucia \& Tangen 2007), art, music and culture (Blue Highway 2003; De Gheyn 1603; Deutsch 2011; Lawrence 2015) and literature studies (Johnson 2012). Some call Qohelet the most Buddhist book of the Bible (Buckley 2016; Lorgunpai 2006). Qohelet is even on Twitter (Qohélet@ FundacionQohelet 2018) and Facebook (Qoheleth Osb 2018).

Moving closer to our own territory, the centuries-long tradition of Qohelet's biblical interpretation requires little explanation. Biblical scholars for much of the late 19th and 20th century took multiple approaches ${ }^{2}$ to interpret Qohelet. One that is still highly influential until today is the historical-critical method, which resulted in a fragmented view of Qohelet's message, alternating between pessimism (Anderson 2000:144, 145; Sneed 2012), optimistic joy (Ogden 1987; Whybray 1982:87-98) and, amongst others, deterministic-positive perspectives (Crenshaw 1990; Fox 1999; Murphy 2002; Rudman 2001) touching on pastoral and pulpit impotence and parishioner indifference.

2.For a history of approaches follow Bartholomew (2009) and for a comprehensive typology of the spectrum of distinct, albeit overlapping philosophical approaches to Qohelet, see Gericke (2015), Christianson (2007) and Bartholomew (1999). 
Is the 'dizzying discipline' of current Qohelet research detached from its spiritual roots? Few interpret Qohelet's spiritual dimension, 'incarnated in life'. Engagement with the text is stale. As Christianson (2007) holds so eloquently:

the stuff of the interpretation of Qohelet - the articulation of words and the pursuit of understanding especially - is marred by fatigue, cognitive exasperation and endless publication. Rendering such boundless hermeneutical energy has required the use of fat paintbrushes, often resulting in far simpler lines than the subject would demand if examined more closely (though often that scrutiny has been more comprehensive than the lines suggest). (p. xiii)

The Qohelet discourse seems to be forced to a painful conclusion: current Qohelet research finds itself derailed, in a 'condition of pluralism and fragmentation' (Bartholomew 2009), even polarisation, and with 'a lack of imagination' (O'Brien 2011). For some, 'the words used to speak of God and spiritual things became divorced from the ideas and affections to which they referred' (McClymond 1997:198). What do postmodernist deconstructionists use as sources? From a library and information science (LIS) perspective, Senapatiratne (2014) makes the case that:

Biblical scholars of Qohelet are often guilty of using materials they are familiar with and ones that they know will already agree with their predetermined academic positions, rather than the most current (and best) sources. (p. 20)

Overly pessimistic or optimistic theological, social, psychoanalytical or political theories that pursue objective or neutral interpretation (Clouser 2005) can be a mere mechanical reproduction, bypassing Qohelet's description of life. The dichotomy, however, opens up a gap through which the 'thread of consciousness' (Christianson 2007:46) that holds Qohelet together faintly glistens. Do we peer deep enough? While this is not an attempt to give a complete understanding, in my recent role as a Cancer Association of South Africa (CANSA) Community Mobiliser in different townships, transformation, specifically personal spiritual transformation, has (had to) made it possible to enter as a Christian and a theologian into Qohelet's spirituality ${ }^{3}$ (Steenkamp 2010, 2011). What is needed in Qohelet studies is that abstract reductionist Cartesian epistemology (Fox 1989), 'shalomic' perspectives (Bartholomew 1999:16), psychoanalytical theory (Bundvad 2016; Helsel 2010), protoexistentialistic perspectives (Enns 2011:31; Fox 1999:133) and social-psychological models (Sneed 2012) ${ }^{4}$ should opt not just to accommodate specific structural analysis or social circumstances but to incorporate Qohelet's spirituality as well.

\footnotetext{
3.The term 'spirituality' goes back via the French spiritualite to the Latin spiritualitas. It is rooted in the biblical semantic field of ruach, pneuma. The Hebrew word ruach has three areas of experience: (1) In the sphere of air, wind, and storm, the ruach shows itself as a power which is in motion (Jr. 4:12; Ex. 1:12). It sets other things in motion (Ps 1:4; Is 7:2; Ex 10:13) (Albertz \& Westermann 1997:1202-1220). Waaijman defines spirituality as 'the divine-human relational process of transformation' (2002:312). Gardener (2011) describes spirituality as that which gives life meaning and that which connects one with a sense of something greater. For some it is religious faith with its traditions and rituals. For others, it might be For some, it is religious faith with its traditions and rituals. For others, it might be 2014:169-170).

4.For more on Qohelet in the light of the history of interpretation, see Longman and Enns (2008:140-149) and Lohfink (2003:3-4).
}

I will, on the one hand, keep in mind over-simplification and the interchangeable use of 'joy', 'happiness' and 'pleasure' in scientific (Fan et al. 2014), popular literature (Altman 2012; Lambert 2014) while taking into account the work conducted on Qohelet's polar structure (Loader 1979). On the other hand, I will carefully avoid 'flattening out the contours of the book'. Keeping an eye on Murphy's claim that 'no one will ever succeed in giving a satisfactory outline of the contents of the book' (1955:304-314), this article will, not unlike an embroider, humbly opt to offer an 'overarching' or comprehensive (Murphy 1992:xxxvii-xxxviii) theoretical framework. This framework aims to provide a spiritual journey that holds the book together, an element that was until now absent in the discourse on Qohelet, ${ }^{5}$ that is, spiritual transformation as a hermeneutical approach.

\section{Spiritual transformation in Qohelet}

The research on Qohelet's spiritual dimension, incarnated in life, is few. This section explores spiritual transformation as a theoretical framework. The foundation of spiritual transformation is already present in Qohelet as noticed by some scholars. Enns (2011:150) indicated that Qohelet underwent a 'transformation of sorts', but does not indicate how. In the opinion of some scholars, Qohelet's transformation can be epistemological (Bartholomew 1999), moral (Perdue 2008:31, 62, 412) or cosmic (Perdue 2008:328). Pigg (2016) states that post-colonial adjustments in Qohelet are to be expected:

If power is beginning to fall apart, then the question would certainly be more apparent about how one might conduct one's self in the current moment. That the images of self-monitoring, fear, suggested solutions, the whispers of a post-colonial understanding of life around tables of eating and drinking and perhaps an implicit wish for change would surface, should not be a surprise (pp. 19, 20).

Transformation is evident in Qohelet's transformed proverbs (Schultz 2015:65), law, story, poetry (Tanner 2001:2) and a newly interpreted law of vows (Levinson 2015:38). According to Homrighausen, Qohelet counselled 'practices of transformation, or can be read with those practices in mind' (2014:4). Deacy is on the verge of metre les point sur les $i$, that is, spiritual perception, ${ }^{6}$ with his statement that 'There is little hope under the sun except through a 'transformation of everyday existence' (2001:90). Paul Marcus, psychoanalyst, is of the opinion that ancient authors such as Ecclesiastes not only identify, with startling brilliance and poetic insight, some of the central problematics of the human condition as modern people construe it but offer what he believes is, in many ways, a reasonable and feasible attitude towards contemporary life that is a better narrative for the human condition and a more compelling technology for selftransformation, self-actualisation and self-improvement (Marcus 2003:6)

5.I will not strive for 'a new reading to replace the old, but to supplement the accepted framework of understanding' (Hamm 2015:viii) with an alternative possibility.

6.Spiritual perception links idea and emotion, the cognitive and the affective. It connects theology with spirituality. There is no dichotomy between the spiritual sense of divine things and the philosophical, theological and historical reflection (McClymond 1997:216). 
As part of an on-going research trajectory, I will look at how initial signs of spiritual transformation become visible in Qohelet. Spiritual transformation is not 'ceaseless change' (Knopf 1930:196) that leads to a 'negative evaluation of life' (McCabe 1996:92) and ultimately to a devaluation of life. It can be understood as 'the restoration of the divine-human relational process in mutual embrace' (Waaijman 2002:463). It is not just an experience but 'a radical reinterpretation of his understanding of God's actions in and will for the world' and of one's 'own consciousness' (metanoia) (Waaijman 2002:34,439,463). From a film perspective, Deacy (2001:4) observes that 'as humankind evolves, traditional religious doctrines and assumptions will necessarily be subject to revision, and even to transformation'. Qohelet's 'intense spiritual experience led to new horizons, and as a result reoriented the axes of his ${ }^{7}$ spirituality "in terms of his contemporary experience"' (Peters 2013:79). His lived experience $^{8}$ is a path of spiritual transformation whereby he intensively lived his relatedness to God and in that way 'blazed a spiritual trail'. Manifest in his journey towards a restored relation (reformation, conversion) was, amongst others, the infinite mercy of God (Waaijman 2002:463). Transformation is in its essence spiritual and spirituality is in its essence transformational (Waaijman 2002:455).

Spiritual transformation goes through different forms (or stages). Humans have an infinite horizon of experiences of the Transcendent God (Rahner 1984:61) that are 'continually unfolding' (Chimhanda 2013:2). Spiritual transformation is not a linear process though. Qohelet appears as a 'motion picture - made up as a series of small discontinuous frames' (Landy 1990:102). Waaijman points out that spirituality is:

\begin{abstract}
A human enterprise with moments of real growth and false growth, inwardness and self-transcendence, a search process and a divine enterprise with moments of revelation and eclipse, a phased and layered process (2002:424). During what Waaijman (2000:658; 2006:44) calls 'transformation in re-creation' or reformed existence, new, fresh opportunities and new possibilities emerge (Hermans 2013:172) ${ }^{9}$ (it will be illustrated in the stages discussed below).
\end{abstract}

A person can, however, during the transformation process choose to go forward (reformation) or turn back (deformation). ${ }^{10}$

Qohelet has the potential to greatly enrich our understanding of how deformation and reformation work. Sharp (2009:202)

\footnotetext{
7.The transliterated word 'Qohelet' is not a person, but means 'preacher'. 'Ecclesiastes' means 'one who calls an assembly' (Cook 2009:1109) 'more like a pastor'. Some biblical scholars are of the opinion that Qohelet might be written by more than one author (Ryken 2010:15-18). I agree, but will for the sake of uniformity and continuity use 'his'.
}

8.Qohelet's experience is a 'living human document' (Boisen 1952:185) of God's presence in the world. It is the primary 'text' of our analysis - opening a new window to our understanding of Qohelet.

9.The promotion of positive psychology is outside the scope of this article. This study does not hinge on positive organisational scholarship, that is, the assumption that things can be improved only if we know more about what makes people thrive or excel in their environment (Roberts 2006:294). I will rather focus on Qohelet's own excel in their environment
spiritual transformation.

10.For a comprehensive scholarly study with a full discussion of his five types of transformation see Hermans (2013:172-173). and Berger (2001:174) found that the book Qohelet is embedded in the author(s)'s personal identity and experience that is shaped by his inner and outer horizon. Waaijman (2002:538-542; 2007:3) distinguished, based amongst others on Edmund Husserl's (1973:32) two horizons, an outer horizon and an inner horizon. ${ }^{11}$ The religious texts of his time 'as measured by religious beliefs and religious activity' (Leon \& Pfeifer 2013), the Torah and the interpretation and applications thereof were the outer horizon of his broader world. It provided him with instructions for his 'life and life situations' (Lombaard 2015:4). He interpreted his world and interacted thereupon. His spirituality, however, unfolded in a post-exilic context. He lived at a time(s) of upheaval when the 'traditional ways of living were giving way to rampant capitalism and trade, when the gap between rich and poor was expanding' (Seow 1997:33-36), reflecting a vast array of different and changing moral systems, epistemologies and religious understandings (Perdue 2008:3) in different time frames. ${ }^{12}$ As these outer horizon(s) shifted, Qohelet's spirituality shifted. He gradually developed new insights that prompted surprising spiritual transformation. In the book, Qohelet described his journey (Enns 2011:201) as we call it in Africa, his safari to spiritual growth.

The argument is that in order to return to the spiritual tradition of transformation and to revisit the dynamic roots of Qohelet, studies of Qohelet have to undergo a paradigm shift in theory formation: from a fragmented to a transformational, processual approach. ${ }^{13}$ I will dare ' $[b]$ eyond the desert of criticism' (Nathan 2014:16) to enter ${ }^{14}$ one of the horizons, namely the inner horizon. Its transformative power and the way that the divine-human relation takes shape (Hausherr 1937) 'seldom received mainstream scholarly recognition' (Lombaard 2014:473). To understand Qohelet's lived experience, I will draw upon the theoretical framework of spiritual transformation developed by the Dutch professor of Spirituality, Kees Waaijman (2002). I will take into account that in these horizons, Qohelet encountered formation and deformation ${ }^{15}$ on his (or their) way to spiritual transformation. plus cultural environments. The inner horizon is the configuration of one's spiritual transformational experience, being the practice of virtues, prayer practices (Waaijman 2002:3). I would like to broaden the above definition of the outer horizon by adding obsolete beliefs. My reason being that when a person's religious convictions (that is supposed to transform the person) broaden or attenuate, so does the person's inner horizon. According to Qohelet, some of his orthodox or traditional beliefs formed him but no longer transformed him. It became stagnant and as a consequence became his context. His previously obsolete beliefs shifted to his outer horizon.

12.For more on Qohelet's outer horizons, compare Qohelet's socio-historical (Barbour 2012: Fishbane 1998; Perdue 2008), socio-political (Berquist \& Hunt 2012; Sneed 2012), religious (Kronholm 2015:448; Perdue 2008), socio-economic (Seow 1996:171-189), cultural (Fontaine 1982; Jarick 2016; Lohfink 2003:viii), linguistic 1996:171-189), cultural (Fontaine 1982; Jarick 2016; Lohfink 2003:viii), linguistic and conceptual (Longman \& Enns 2008:132-140;
surrounding cultures in different historical contexts.

13.Spiritual transformation's processual architecture does not equate with Process Theology (Hartshorne 1953; Whitehead 1929, etc.). The latter's focus is on arguments for the existence of God. The former emphasise lived experiences regarding God.

14.I will be cognisant of the fact that 'only with a relentless desire to enter, read in the right way - with sympathy and imagination, no condescension - can ancient texts come back to life, and let us in their world, their way of seeing, to take the measure of things that are strange (Kugel 2003:192 author's own italics).

15.In a previous book, Chapter I distinguished between three types of spiritual transformation, following the work by Kees Waaijman (Spirituality: Forms, Foundations, Methods (Dutch 2000; English translation, 2003), that is, deformation, reformation and transformation. Deformation is conformity to the world. One has 


\section{Joy as an aspect of spiritual transformation in Qohelet}

Qohelet was on a journey during which his viewpoints changed. The spiritual transformation, theoretical framework reviewed above provides a detailed description of the fragile process that may lie in the background of Qohelet's journey. In spite of the flow of commentaries, the book's joyous underpinning leading to the overturning of his spiritual status quo has been consistently overlooked, not yet been sufficiently explored and thus unappreciated. To provide clarity and enhance understanding of spiritual transformation, the analysis will be done based of the key word 'joy', delineating four phases, stages or movements in a diachronic perspective. ${ }^{16}$

Qohelet's safari can be described as liminal, belonging to different states and statuses. Qohelet's experience is liminal because he was sandwiched between an initial insider and thrice an outsider by virtue of his religious orientation, in between a sage-king and a sage-writer(s), and betwixt a privileged lawmaker and a sub-class enjoyer or merrymaker. This inner transformation can be detected in form and expressions. Being a religious person, Qohelet reacted to the issues of his time in the 'language of his spiritual experience' (Waaijman 2000:651). The repetition of the keyword" 'joy'18 (or what Robbins called the inter-texture or interactive world' 1996:40) provides a 'hermeneutical clue in arriving at a balanced, text-centred approach'19 (Fuhr 2008:28; Waaijman 2000:238, 669, 93). Joy's interpretation as a 'metaphorical frame of reference' undergone a profound dynamic transformation. Considering that textual inconsistencies are 'writerly' attributes (Thiselton 1992:98), the aim is to indicate how the changing face of 'joy' was introduced, put together and even left in the text by the editor(s) to note the way Qohelet related personally to God. Qohelet's apparent 'cacophony' is because of his recognition of different spiritual stages without making a specific stage normative. Taking into account that 'delimitation is also a reduction' (Cilliers 2008:3), four phases, stages or movements will be distinguished, but can in fact not be separated. These are experimentation, reinterpretation, realignment and recommitment.

\footnotetext{
(footnote 15 continues)

no prospects or hope, as well as limited by people or situations or yourself, self-orientated or self-absorbing (Waaijman 2006:44, 460-463). Reformation proceeds from God. It entails a renewal of the mind to distinguish what is good, distinguishable by action. Transformation is a reversal, a return or a U-turn to the original interpretation of God's actions and will for the world, the relationship with God, followed by a return of God. Because spiritual transformation is not linear, but God, followed by a return of God. Because spiritual transformation is not linear, but
a process, individuals can oscillate between ecstasy and confusion, a feeling of nothingness, but withal triumph (Steenkamp-Nel 2018a:164)

16.A diachronic perspective illuminates a gradual change or developmental path of a text or a term's meaning.

17.A Leitwort is a keyword: that recurs significantly in a text, in a continuum of texts, or in a configuration of texts: by following these repetitions, one is able to decipher or grasp a meaning of the text, or at any rate, the meaning will be revealed more strikingly (Alter 1981:93).

18.I recognise that there are additional constructs beyond those dealt with in this article within the text of Qohelet. I will focus on 'joy' as leitword.

19.While appreciating Loader's Polar structures (1979), I derived my notion from the spiritual transformation process of deformation and reformation. For more on the death-joy theme follow Sabo (2013).
}

TABLE 1: Ecclesiastes - Text and translation.

\begin{tabular}{|c|c|}
\hline Ecclesiastes & Translation \\
\hline 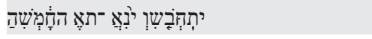 & $8: 15$ I praised joy (NAB). \\
\hline המַ-הזֹ השָעע. & $\begin{array}{l}2: 2 \text { and of joy - What use is it? (Bible in } \\
\text { Basic English). }\end{array}$ \\
\hline 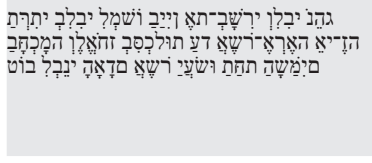 & $\begin{array}{l}2: 3 \text { I searched with my mind how to cheer } \\
\text { my body with wine-my mind still guiding } \\
\text { me with wisdom-and how to lay hold on } \\
\text { folly, until I might see what was good for } \\
\text { mortals to do under heaven during the few } \\
\text { days of their life (NRSV). }\end{array}$ \\
\hline 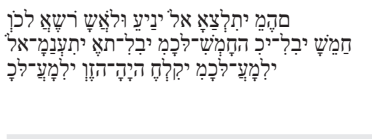 & $\begin{array}{l}\text { 2:10 And whatsoever mine eyes desired } \\
\text { I kept not from them, I withheld not my } \\
\text { heart from any joy; for my heart rejoiced } \\
\text { in all my labour: and this was my portion } \\
\text { of all my labour (King James Bible). }\end{array}$ \\
\hline 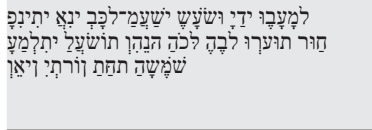 & 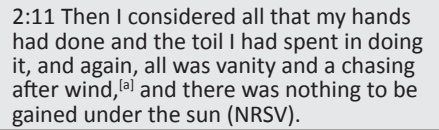 \\
\hline
\end{tabular}

\section{Experimentation: Joy in things}

Qohelet calls for joy ${ }^{20}$ in seven key texts (Ec 2:24-26, 3:1213,22, 5:17-19, 8:15, 9:7-10,11:7-12:7). Joy and contentment are found in Ec 2:24; 3:12-13,22; 5:18-20; 7:4, 8:15; 9:7-9; 12:13-14 depicting work, eating and drinking, marriage and family. Although he valued 'joy', he denigrated the futility of his positive remark: 'I praised joy' (8:15 NAB Translation) with the apparent antitheses: 'joy - What use is it?' (Bible in Basic English) (Ec 2:2). He exemplified this pyrolysis, meaning a meltdown or cleaning out of old idea(s) in Ec 2:3, 10-11 (see footnote 13 and Table 1). As an example hereof, he initially had the impression that the Torah was bliss. It was soon followed by the empiricist (Redding 2013:31) experiential idea that 'joy is things' (Ec 2:10) (Barbour 2012:167). As a result, he began to seek or strive for prosperity $(2: 4-7)$, progress $(2: 8,9)$ and personal tribute $(2: 10)$ (Lohfink 2003:46-51). This contextual or constructivist view of 'joy' is implied by Bible translations that render the expression 'pleasure'. The above two types or stages or aspects of joy (Fishbane 1998:154) $^{21}$ are not a juxtaposition or contrasting emotional registers nor has the two verses, the same meaning (Kruger 2004:3). The differentiation between the above two types or stages or aspects of joy (Fishbane 1998:154) is an example of Qohelet's oscillation between deformation and reformation.

This new view brought no happiness though (Ec 2:11), and Qohelet encountered (through wisdom) ${ }^{22}$ deformation. He was distressed, filled with sadness and overcome by frustration (2:12-23). As Fuhr $(2008: 14,15)$ and Fox (1999:113) state, 'joy is commended throughout the book (Ec 2:24-26;

20.The idea of joy is expressed in the Old Testament by a wealth of synonymous terms that cannot easily be differentiated. The commonest is simchah (1 Sm 18:6, etc.), variously translated in English Versions of the Bible 'joy', 'gladness,' 'mirth'; from sameah, properly 'to be bright,' 'to shine' ( $\operatorname{Pr} 13: 9$, 'The light of the righteous rejoiceth,' literally, 'is bright'), but generally used figuratively 'to rejoice', 'be glad' (Lv 23:40 and very frequent) (Edwards 1997:689). Ancient pictographic Hebrew letters depict 'joy' as 'a spontaneous expression of excitement and cheer' (Benner 2005:393).

21.Whybray (1982) is perhaps best known in the world of Qohe1et studies for his 'enjoy life' motif. According to Gordis (1968), the basic theme and commandment of the book are 'to enjoy life'. Seow (1997) emphasises the instruction to enjoy life in the midst of dire circumstances. Lee $(2005: 86,122)$ combines the 'enjoy life' message, with the fear of God. My look at joy is from the perspective of spiritual transformation.

22.Compare Fuhr (2008:109) 
3:12-13; 3:22; 5:18-20 [Heb 17-19]; 8:15; 9:7-9; 11:9), while pleasure is questioned as to its value (follow Ec 2:2-3, 10-11)'. The reason being that 'joy differs from the pleasures of projection because it requires us to keep in mind the duality of affective life' (Gay 2001:42). It is as if Qohelet deliberately created tiny holes in the text for a lacy effect. These nuances in the text give us a glimpse of the New Testament deformation spiritus-spiritualis analogously with carnocarnbalis. Joy can be corrupt, self-absorbed (rejoice only in a person's own good) or the perverse (rejoicing in the misfortune of others called 'schadenfreude') (Yale Center for Faith and Culture 2016).

As the twisting of embroidery's thread can result in a lot of fraying and tangling, incompleteness or brokenness can cause 'tension' in Qohelet (Morgan 2011). I would qualify the statement: Qohelet's 'deformation causes spiritual tension'23 because the 'inner journey' is 'tension-producing' (Waaijman 2002:38). This field of tension plays a vital role in spirituality (Waaijman 2002:362). During the spiritual journey towards authentic existence, the absurd creates a tension necessary to the maturation and authenticity of the religious person (Morgan 2011:15). Tension has a function. It urges Qohelet to move. He develops an urge to further transform as illustrated by his understanding of God.

\section{Reinterpretation: Understanding God anew}

Although Qohelet's journey was deeply transformative, his journey was not a 'complete, but an unfolding experience' (Lombaard 2015:3). He was in the practice of pulling the layers away. His layered understanding of joy unfolded because his understanding of God unfolded (Sekine 1999:118). In earlier Jewish thinking, institutionalism (temple) and legalism (Torah) guaranteed God's rewards or punishment (Sekine 1999:126). Salvation was synonymous with slavish obedience. God was rituals and rules (Perdue 2008:252). Qohelet and his contemporaries, however, we're asking very different questions than the ones put forth by the Torah devotees. They reflected on the horrors of the Babylonian exile and the series of 'collective' losses. Behind Qohelet's individual experience was the appropriated experience of the whole nation (Fishbane 1998:116). These experiences cultivated a painful awareness that causal rules guarantee nothing (Sekine 1999:126). Torah adherence in order to guarantee self-preservation is vanity. 'Love for the exclusive self' is hollow. Joy is rather the 'willing performance of the commandments and service to God' that 'leads to divine inspiration' (Fishbane 1998:155-158). Qohelet's perception of God changed too. God is not just rules (torah) and ritual (Lohfink 2003:57; Perdue 2008:253; Sekine 1999:26) or give just rite and ritual. God gives joy (Ec 2:24, 25, 3:13, 9:7, 9:9). 'Moreover, when God gives someone wealth and possessions,

23.The tension in Qohelet (Enns 2011:124) is not just psychological (Weeks 2011:177) structural (Berger 2001:155, 158), hermeneutical (Enns 2011:46, 47, 95, 102;
Longman 1998:26, 27, 134), cultural (Enns 2011:57) existential (Camus 1991), Longman 1998:26, 27, 134), cultural (Enns 2011:57) existential (Camus 1991),
theological (Enns 2011:125) or political-economic (Garret 1987:159-177). It is spiritual tension too (Waaijman 2002:461). I do not deny the tensions and even necessity of a stressful engagement with the text. Narrowing of the hermeneutica endeavour to oppose and exclude tension considerations is not my goal. I would like to contribute towards expansion or broadening of the hermeneutical voyage to contemplate complementary spirituality in the text. and the ability to enjoy them, to accept their lot and be happy in their toil - it is a gift of God' (Ec 5:19 NIV). God gives joy he therefore wills joy:

Enjoy life with your wife, whom you love, all the days of this meaningless life that God has given you under the sun - all your meaningless days. For this is your lot in life and in your toilsome labor under the sun. (Ec 9:9)

To be joyful is Divine will. As a result, Qohelet places joy in the core of human life because God, who gives joy, is at the core of human life. He was no longer frozen in a literalist interpretation of the Torah. He became spiritually defrosted.

\section{Realignment: Enjoy with God}

A realignment towards God followed. Joy with God became valued. It is in sync with Waaijman's statement that emotion's function is to move us past the visible to the Infinite (Waaijman 2002:241). In contrast with Sneed (2012:225) that dismisses Qoheleth's joy statements as an irrational response, a kind of 'drug that enables him to endure the painful existence of life' (Lang 1979:119-120) and Anderson's statement that the 'so-called joy statements of the book' are probably 'ironic (pessimistic) tropes' 'as a means of coping with the reality of life' (2000:153). Waaijman emphasised that affection and enjoyment direct us to the invisible things (Waaijman 2000:1241).

Enjoyment also directs us to the practical. On Qohelet's spiritual journey, he went through deformation to reformation. In Ecclesiastes 9:7-10, his earlier commendations (Ec 2:24, 3:13) were converted in imperatives 'eat, drink and enjoy life' and bread to be eaten in joy (Ec 9:7, 11:1-2). To give in hospitality became the communal embodiment of joy (Brown 2011:93,129). Joy became the joy in the small things of everyday life because 'God is in the small joys of everyday life' (Sekine 1999:119). God is joy. Joy is not 'merriment unconnected to any religious duty' (Fishbane 1998:155). That is hedonistic pleasure. Joy is not naïve optimism, what Michael Medved simply calls 'Hollywood' (Medved 1992). Joy is in the small things: eating, drinking and enjoying (Ec 2:24) 'inspired by God' (Gianto 1992:530). Joy in simple pleasures is sacramental (Lee 2005:122). This insight was triggered by the post-exilic realisation (reinforced by Hellenism's rising influence) of the exilic principle's deeper meaning, 'I am what I am' (Ex 3:14) (see Waaijman 2002:435). God's name, 'I am', indicates that God is not just a God of doing, but also of being. Therefore, he asks of us not to dim or reduce ourselves to just 'human-doing' or 'human-having', but to 'human-being', that is 'to enjoy', and sometimes just 'be'. The transcendent should glisten through the immanent.

Qohelet hitherto experienced reformation. He perceives joy in a new light. The concrete world of everyday life became the basic material for an encounter with God (Brown 2000:14; Waaijman 2002:14). God incarnated in lekker [Africa's youngest indigenous language; Afrikaans word for 'nice'] becomes joy. Joy matters, not just because life is short (Fox 1999:179), death is near (Longman 1998:227-231), and God is 
alive (Murphy 2002:125-126). Joy matters because it is an act that indeed produces internal transformation (Lee 2005:67). The crest of joy is a 'perpetual birth' that 'creates and recreates those who give themselves to it' (Metz \& Jossua 1974:89). It breaks down the dichotomies between matter and spirit and enhances our ability to actualise more potentialities (Liston 1996:121). Joy is a spiritual transformational act. Act joyful and life's joyful 'opportunities and internal possibilities' (Brown 2011:93) unfold. Joy is 'to open yourself up to all the different experiences that life has to offer'. To act joyfully is to become joyful. Joy becomes an index for transformation and takes the form of a call to energetic action (Ec 9:10, 11: 4-6) because 'all is perfectly in its time' (Ec 3:10-14) (Lohfink 2003:60).

The point is that joy in Qohelet is not just an emotion. Joy is not 'fragile' (Metz \& Jossua 1974:11). Joy is a conductor of the good, authentic (Liston 1996:36; Lohfink 2003:75) life - not in an instrumentalist way (Lombaard 2012:68) or constructivist way, but joy as an orientation and a 'response to God's activity' (Niemandt 2016) that recreates, renews and revitalises lives. 'Joy produces energy. Joy makes us strong' (Foster 2008:239). Joy moves us and inspires us to move.

Joy is the expression and manifestation of the good life, and the good life cannot be envisioned in its fullness without reference to joy. Joy casts a positive vision of what life is truly for (Crisp 2015:183). Transformation is an invitation to personal reformation in addition to everyday joy. Joy is the 'crown' (Crisp 2015:xiv). To enjoy without God is only pleasure. To enjoy with God is joy. Pleasure is situational. Joy is transformational. Qohelet's joy gave readers a view of a future horizon.

\section{Recommitment: Joymotion (with others)}

The above three stages build upon each other. It is, however, important to take note of the fact that Qohelet was still susceptible to deformation. His engagement focused on the Other, but not yet on the other (Sekine 1999:126, 127). 'God is joy', but not yet 'God is (in) you (neighbor)'. Love was 'love for God', but not yet 'love for others' (Sekine 1999:127). Self-realisation did not yet develop into self-actualisation. Qohelet's deformation was in the form of his incompleteness. On his journey, he rethought and critiqued earlier thinking while practising 'bifocal' spirituality. He interacted 'fully in the concrete world of his physical and social existence, yet is sustained in it, by a vision of humanity that is still in the making' (McConville 2013:73). There was admittedly a backstitch. Later in Israel's history, Qohelet was being read during the Jewish Feast of the Tabernacles (Knauth 2003:28, 30). During acts of joyful hospitality towards rich and poor guests and the festive harmony with others, 'cultural padeia' pointed towards the next phase of spiritual transformation as applied spirituality (Aejmelaues 2003:502; Fishbane 1998:157).

In contrast with Roberts (2013:35) who perceived joy as one of the 'most obvious emotional manifestations of a well-lived life', Moschella described joy as 'developing practices' of 'compassion that opens us out to the spacious joy of recognizing our connection to each other, realizing that we are not alone or limited to/by our own resources' $(2015: 104,124)$. It is an embroidered or embodied awareness of a holy presence and extravagant love (Niemandt 2016). Happiness is thinking of myself; joy is thinking of others. Joy as an aspect of spiritual 'transformation is at the heart of societal transformation' (Provan 2011:11). Joy moves us to service, because God incarnated in the sensorial becomes service:

Joy can be generous; joy can be attuned to the suffering of others (as when, in a period of intense joy, we continue to be mindful of those who grieve). It may be what most distinguishes joy from happiness and why, despite the recent glut of happiness research, our culture still needs careful consideration of joy. (Yale Center for Faith and Culture 2016)

To eat and drink while enjoying is an 'existential involvement in the God-given sanctification as perceived by the senses' and 'reformation at a sensory level'24 (Waaijman 2002:177, 462). By eating and drinking with others, one is 'born into a new world, which points away from the self' (Waaijman 2002:176). 'Physical spaces serve as vital sources of metaphors for the social construction of reality' (Olivier 2006:5). So, joy is not an emotion. Joy in Qohelet is 'joy in small things' in transit to 'joy is love for others'. In the previous phase, Qohelet became aware that the agency was not with the individual. The initiative was/is with God. Where the dynamic between the parties begins and ends is a mystery. To manage (on) the earth became a mutual endeavour.

Qohelet is a bridge to the New Testament (Sekine 1999:126). Compassion, service and volunteerism are the next level/ stage or movement where joy is 'jo[y]in' (Steenkamp-Nel 2018b).

\section{Spirituality of joy in Qohelet}

The problem of continuity and change is felt acutely in Qohelet. Qohelet is however not an 'unsystematic thinker' (Fox 1999:71) who sprouted an 'odd' (Crenshaw 1990:28) or 'disjointed' text (Sekine 1999:95) that resists a unified interpretation, circumventing the mysteries of God. Qohelet's search is all about understanding God in a new and fresh way. Stagnation and fixed ideas are excluded from Qohelet's theology. Keeping in mind that 'highly gifted redactional craftmanship' requires 'decidedly intellectual, textually vigilant readership' (Lombaard 2007:356), my volte-face [U-turn] to answer Qohelet's invite was to ascribe meaning to the subtler ways than has been explicitly noted. The way in which the text's Brodeur [gold thread embroidery] conveys spiritual transformation is not by labelling change per se, but by employing tone and repetition. Qohelet's pyrolytic change in tone and approach corresponds to and was influenced by religious frameworks, traditions and practices (Fishbane

24 The process by which we inwardly know an interior from signs that have been given from without through our senses is called 'understanding' (Waaijman 2002:661) The orientation of the body assists humans to orientate their soul towards the realisation of God. 
1998:151). Constant reinterpretations and reformulations in reaction to new insights followed. There are no clashing religious interpretations of joy. The spiritual transformation in the book is witness to how Qohelet continuously, spiritually adapts within his changing surroundings. The four phases or stages are enough to indicate a movement, a transformative process regarding Qohelet's spirituality. Qohelet grew from exilic liberation to reformation, from self-preservation to selfcriticism (or self-realisation), from a clerical focus to a new everyday spirituality, that is, 'transformation-in-reformation' (Waaijman 2000:24, 25; 2002:194, 900).

Qohelet was a pioneer and a catalyst. Spiritual transformation provides a hermeneutic tool with which to interpret the book. Qohelet's own transformative interpretation is dynamic, contextual and diachronic. He showed how his life had been changed. He became less attracted to his world's zeitgeist, that is, 'cui bono' [self-interest]. His counterspiritual critique of the mainstream spirituality expressed a lived experience of spiritual transformation from a law abider to a pleasure seeker to a merrymaker. His 'joy texts' does not denote 'individual hedonism', but was rather an intention to eventually 'shape societal structures' (Oeming 2006:43, 44) through individual spiritual transformation. Joy is the force that allows the enjoyer to enter a humanGod discourse that brings about spiritual transformation. That is why it is a book of discomfort and feels so postmodern.

Spirituality at this stage in Old Testament spirituality's development is growing from 'God is rules' to 'God is joy' on its way to the New Testament 'God is (in) you'. It travels from legalism through self-indulgement and self-realisation on its way to the New Testament's self-actualisation (see Figure 1). It weaves the golden thread from 'love for self' to 'love for God' on its way to 'love for others'. It glistens through vanity to transcendence. Joy is the stepping-stone, bridge, dynamo or conductor for this movement, leapfrogging the old spiritual infrastructure and choices, challenging and changing the DNA of its timeframe. Qohelet is not about paradox, but about a process. It is not about balance, but about movement, not being just observational, but transformational. Qohelet has not a heterodox character, but a transformational character.

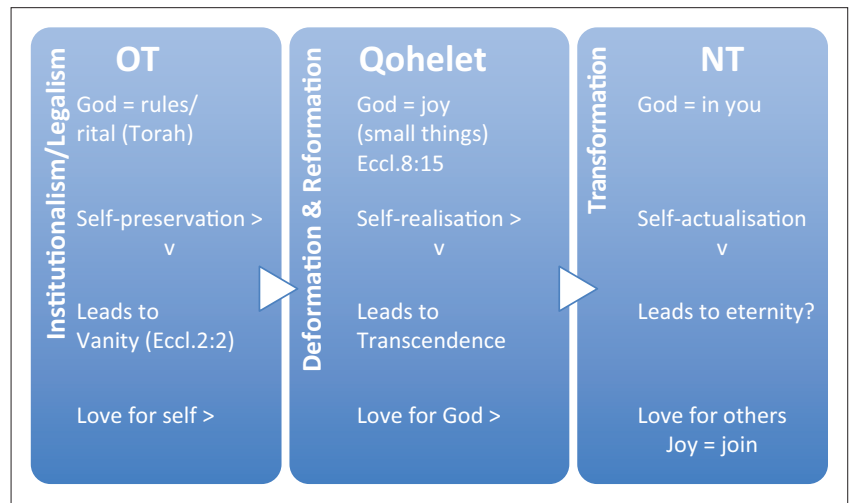

FIGURE 1: Spiritual transformation in relation to joy in Qohelet.
To avoid essentialism (attention on phases of the whole) spirituality's constantly changing disposition drives us towards the development of broader scholarship. Hence, I suggest a critical study on spiritual transformation Bible narratives. 'As various forms of social marginalization and injustice are becoming better understood' (Moschella 2015:101), it becomes increasingly important to make room for the spiritual transformational approach in biblical hermeneutical approaches on the pulpit and in the pews. Soft attentive voices (in transit) on church board meetings and synods instead of impressive articulated modernistic roars may well carry important insights. Perceptions limited by, and exactly because if their limitedness, because of the spiritual stage or phase it is in, have value. It is indeed because of their limitedness that they have to be heard. Their faint luminesce can throw a light on the stage we are in and the next stage we must move on to.

\section{Conclusion}

I offered an overarching framework that holds Qohelet together that was until now absent in the discourse. Qohelet contains aspects of all of the Qohelet theories suggested, but not simultaneously and not in perpetuum. The tension between clashing and complementing religious attitudes in Qohelet reveals that Qohelet's spirituality is transformational.

My hermeneutical approach of spiritual transformation focused on Qohelet's dynamic, contextual and diachronic character honouring the reformational motto: sacra scriptura sui ipsius interpres. Joy as an aspect of spiritual transformation is the faintly glistening thread that holds Qohelet together. It is of profound importance because it represents not only a spiritual shift but moreover a commitment to change the attitudes of believers. To come to God in faith is not an arithmetical, instant or result orientated affair. It takes time to grow into God(-likeness). Qohelet as a 'bridge book' to the New Testament dispensation shows the (processual) way.

\section{Acknowledgements Competing interests}

The author declares that she has no financial or personal relationships which may have inappropriately influenced her in writing this article.

\section{References}

Achebe, C., 1964, Arrow of God, Doubleday and Company Inc., New York.

Aejmelaues, A., 2003, “"Rejoice in the lord!". A lexical and syntactical study of the semantic field of joy in the Greek Psalter', in M.F.J. Baasten \& W.T. Van Peursen (eds.), Hamlet on a hill. Semitic and Greek studies presented to Professor T. Muraoka, pp. 501-521, Peeters Publication, Leuven.

Albertz, R. \& Westermann, C., 1997, 'Ruach', ThLOT 3, 1202-1220.

Alter, R., 1981, The art of biblical narrative, Basic Books Inc. Publishers, New York.

Altman, D., 2012, The Joy compass. Eight ways to find lasting happiness, gratitude and optimism in the present moment, New Harbinger Publications, Inc., Oakland, CA.

Anderson, W.H.U., 2000, 'Historical criticism and the value of Qoheleth's pessimistic theology for postmodern Christianity through a canonical approach', Old Testament Essays 13(2), 143-155.

Army of Bones, 2017, 'Ecclesiastes', in Army of bones, Bones Music Group, Track\#7, viewed 27 May 2018, from https://www.allmusic.com/album/army-of-bonesmw0003000066 
Barbour, J., 2012, The story of Israel in the Book of Qohelet. Ecclesiastes as cultural memory, Oxford Theological Monographs, Oxford University Press, Oxford.

Bartholomew, C., 1999, 'Qoheleth in the canon? Current trends in the interpretation of ecclesiastes', Themelios 24(3), 4-20.

Bartholomew, G.C., 2009, Ecclesiastes. (Baker Commentary on the Old Testament Wisdom and Psalms), Baker Academic a division of Baker Publishing Group, Grand Rapids, MI.

Benner, J.A., 2005, The ancient Hebrew Lexicon of the Bible, Virtualbookworm.com Publishing Inc., College Station, TX.

Berger, B.L., 2001, Qohelet and the exigencies of the absurd, Koninklijke Brill NV Leiden.

Berquist, J.L. \& Hunt, A., 2012, Focusing biblical studies: The crucial nature of the Persian and Hellenistic periods. Essays in honor of Douglas A. Knight, T\&T Clark, New York.

Blue Highway, 2003, 'Chasing after the wind', in Wondrous love, audio CD, Dark horse Studios, TN. Track \#6.

Boisen, A., 1952, Exploration of the inner world, Harper and Brothers Publishers, New York.

Brown, W., 2000, Ecclesiastes. Interpretation, Westminster John Knox, Louisville, KY.

Brown, W.P., 2011, Ecclesiastes. Interpretation. A Bible Commentary for teaching and preaching, John Knox Press, Louisville, KY.

Buckley, B.D., 2016, Bible read: Ecclesiastes, [Blog]. Brian D. Buckley cryde inky blab, viewed 27 May 2018, from https://briandbuckley.com/2016/08/10/bible-readecclesiastes/

Bundvad, M., 2016, 'At play in potential space: Reading Qohelet's building experiment with psychoanalytical space theory', in J. Jarick (ed.), Perspectives on Israelite Wisdom: Proceedings of the Oxford Old Testament Seminar, pp. 254-276, Bloomsbury, London.

Camus, A., 1991, The myth of Sisyphus and other essays, transl. J. O'Brien, Vintage Books, New York.

Chimhanda, F., 2013, 'Relevance of theology in relation to spirituality: An African Bantu perspective', Scriptura 112(1), 1-17. https://doi.org/10.7833/112-0-65

Christianson, E.S., 2007, Ecclesiastes through the centuries, Blackwell Publishing Ltd., Malden, MA.

Cilliers, J.H., 2008, 'Formations and movements of Christian spirituality in urban African contexts', paper presented at the Conference Interkulturelle Religionshermeneutik - Das Verstehen des Fremden, Religion und Politik in Afrika, Humboldt University, Berlin, 10th July.

Clouser, R.A., 2005, The myth of religious neutrality: An essay on the hidden role of religious belief in theories (revised edition), University of Notre Dame Press, Notre Dame, IN.

Cook, D.C., 2009, The Wiersbe Bible Commentary: Old Testament, 2nd edn., David C. Cook Publishing Company, Colorado Springs, $\mathrm{CO}$.

Cooper, C.L., Quick, J.C. \& Schabracq, M.J., 2015, International handbook of work and health psychology, 3rd edn., Wiley Blackwell, West Sussex.

Crenshaw, J.L., 1990, 'Odd book. In: Ecclesiastes', Bible Review 6(5), 28-33.

Crisp, J.E., 2015, 'Introduction: A bright sorrow', in M. Volf (ed.), Joy and human flourishing essays on theology, culture, and the good life, pp. vii-xviii, Fortress, Minneapolis, MN.

Dante, A., 1350, La Divina Commedia. Inferno c.1r. canto 1-3. Ravenna, Biblioteca del Centro Dantesco, Convento di San Francesco, 2 (Phillips 9589), viewed 27 May 2018, from http://amshistorica.unibo.it/170

Deacy, C., 2001, Screen Christologies: Redemption and the medium of film, University of Wales Press, Cardiff.

De Gheyn, J., II., 1603, Vanitas still life [Painting], The Metropolitan Museum of Art New York, viewed 16 November 2016, from https://za.pinterest.com/pin/ 560627853584587469/.

Deutsch, L., 2011, A time to weep, and a time to laugh [Painting], Lyn Deutsch Art work Collection, Cebu, viewed 16 November 2016, from https://lyndeutsch. wordpress.com/category/paintings-by-lyn-deutsch/page/4/

Douglas, J.N., 2011, Qoheleth: An anti-apocalyptic genre for a message of joy, Marquette University, Milwaukee, WI.

Edwards, D.M., 1997, 'Joy', in E.Y. Mullins (ed.), International standard Bible encyclopedia, vol. 6, pp. 689-692, AGES Software, Albany, OR.

Enns, P., 2011, Ecclesiastes, Wm. B. Eerdmans Publishing, Grand Rapids, MI.

Fan, R., Zhao, J., Chen, Y. \& Xu, K., 2014, 'Anger is more influential than joy: Sentiment correlation in Weibo', PLoS One 9(10), e110184. https://doi.org/10.1371/journal. pone. 0110184

Fishbane, M., 1998, The exegetical imagination. On Jewish thought and theology Harvard University Press, Cambridge, MA.

Fontaine, C.R., 1982, Traditional sayings of the Old Testament: A contextual study, Almond Press, Sheffield.

Foster, R., 2008, Celebration of discipline: The path to spiritual growth, Hodder \& Stoughton Ltd., London.

Fox, M., 1989, Qoheleth and his contradictions, Almond, Sheffield.

Fox, M.V., 1999, A time to tear down and a time to build up: A rereading of Ecclesiastes, Eerdmans, Grand Rapids, MI.

Fuhr, R.A., 2008, 'An analysis of the inter-depency of the prominent motifs within the book of Qohelet', PhD dissertation, Southeastern Baptist Theological Seminary, Wake Forest, NC.
Gardener, F., 2011, Critical spirituality: A holistic approach to contemporary practice, Ashgate Publishing, Farnham.

Garret, A.D., 1987, 'Qohelet on the use and abuse of political power', Trinity Journal 8 NS, 159-177

Gay, V., 2001, Joy and the objects of psychoanalysis: Literature, belief, and neurosis, Suny Press, Albany, NY.

Gericke, J.W., 2015, 'A comprehensive typology of philosophical perspectives on Qohelet', Verbum et Ecclesia 36(1), Art. \#1358, 1-7.

Gianto, A., 1992, 'The theme of enjoyment in Qohelet', Biblica 73, 528-533.

Gordis, R., 1968, Koheleth - The man and his world. A study of Ecclesiastes, 1951 Reprint 3rd edn., Schocken Books, New York.

Hamm, R.F., 2015, 'It's all uphill from here: Finding the concept of joy in existensial philosophy and literature', PhD dissertation, Purdue University, West Lafayette, IN

Harsanyi, M.A. \& Harter, S.P., 1993, 'Ecclesiastes effects', Scientometrics 27(1), 93-96. https://doi.org/10.1007/BF02017757

Hartshorne, C., 1953, Reality as social process: Studies in metaphysics and religion, Free Press, Boston, MA

Hausherr, I., 1937, 'Biographies Spirituelles. II. Époque Byzantine', in M. Viller, C. Baumgartner \& A. Rayez (reds.), Dictionaire de Spiritualité 1, pp. 1634-1646, G. Beauchesne et ses fils, Paris.

Helsel, P.B., 2007, 'Warren Zevon's the wind and Ecclesiastes: Searching for meaning at the threshold of death', Journal of Religion and Health 46(2), 205-218. https:// doi.org/10.1007/s10943-006-9072-3

Helsel, P.B., 2010, 'Enjoyment and its discontents: Ecclesiastes in dialogue with Freud on the stewardship of joy', Journal of Religion and Health 49, 105-116. https:// doi.org/10.1007/s10943-008-9224-8

Hermans, C.A.M., 2013, 'Spiritual transformation: Concept and measurement', Journal of Empirical Theology 26, 165-187. https://doi.org/10.1163/1570925612341275

Homan, M.M., 2002, 'Beer production by throwing bread into water: A new interpretation of Qoh. XI 1-2', Vetus Testamentum 52(2), 275-278. https://doi. org/10.1163/156853302760013893

Homrighausen, H., 2014, Tibetan-Christian dialogue, viewed 27 May 2018, from https://www.academia.edu/11220832/Eat_Drink_and_Renounce_the_World Ecclesiastes_and_Tibetan_Buddhism

Husserl, E., 1973, Experience and judgment: Investigations in a genealogy of logic, Northwestern University Press, Evanston, IL.

James, H., 1904, The golden bowl, Charles Scribner's Sons, New York.

Jarick, J., 2016, 'The rhetorical structure of Ecclesiastes', in J. Jarick (red.), Perspectives on Israelite wisdom: Proceedings of the Oxford Old Testament Seminar, pp. 208-231, Bloomsbury, London.

Johnson, B.J., 2012, 'Echoing attitudes: The echoes of Ecclesiastes and T. S. Eliot in look homeward, angel and of time and the river', Master's thesis, Appalachian State University, Boone, NC.

Johnston, R.K., 2004, Useless beauty: Ecclesiastes through the lens of contemporary film, Baker Books, Grand Rapids, MI.

Keiter, S., 2015, 'All is vanity: Virginia Woolf's Orlando and Ecclesiastes', pape presented at the 113th Annual Conference, Hilton Hotel, Portland, Oregon, 6-8 November, viewed 19 January 2015, from www.pamla.org/2015/proposals/allvanity-virginia-woolfs $\%$ C2\%AOorlando-and-ecclesiastes\#sthash.AaxhESuJ.dpuf

Knauth, R.J.D., 2003, 'Feast of weeks and tabernacles', in T. Alexander \& D.W. Baker (eds.), Dictionary of the Old Testament: Pentateuch. A compendium of contemporary biblical scholarship, pp. 28, 30, Inter Varsity Press, Downers Grove, IL.

Knoetze, J.J., 2014, 'Transforming a fragmented South African society through a spirituality of koinonia coram Deo', NGTT (Dewaal Neethling Trust) 55(1), 167-187. https://doi.org/10.5952/55-1-2-520

Knopf, C.S., 1930, 'The optimism of Koheleth', Journal of Biblical Literature 49, 196. https://doi.org/10.2307/3259110

Kronholm, T.T., 2015, 'תתע עע: 'attâ time', in G.J. Botterweck, H. Ringgren \& H. Fabry (eds.), Theological dictionary of the Old Testament, vol. XI, pp. 434-451, Wim B. Eerdmans Publishing Co., Stuttgart, Germany.

Kruger, T., 2004, Qoheleth. Hermeneia - A critical and historical commentary on the Bible, Fortress Press, Minneapolis, MN.

Kugel, J.L., 2003, The God of old: Inside the lost world of the Bible, Free Press, New York.

Lambert, A.A., 2014, The joy of discovering joy in our lives, AuthorHouse, Bloomington, IN.

Landy, M., 1990, 'Humour as a tool for biblical exegesis', in Y. Radday \& A. Brenner (eds.), On humour and the comic in the Hebrew Bible (Bible and Literature Series, 23), pp. 99-116, Academic Press, Sheffield.

Lang, B., 1979, 'Ist der Mensch hilflos? Das biblische Buch Kohelet, neu und kritisch gelesen', TQ 159, 109-124.

Lawrence, M., 2015, Chasing after the wind. Ecclesiastes 1:14 [Painting]. Mark Lawrence Gallery, Boston, MA, viewed 16 November 2016, from https://www. marklawrencegallery.com/products/ecclesiastes-1-14-chasing-after-the-wind

Lee, E.P., 2005, The vitality of enjoyment in Qohelet's theological rhetoric, Walter de Gruyter, Berlin, Germany.

Leon, A.K. \& Pfeifer, C., 2013, Religious activity, risk taking preferences, and financia behaviour: Empirical evidence from German survey data, Working Paper Series in Economics. No. 269, University of Lüneburg, Lüneburg. 
Levinson, B.M., 2015, 'Better that you should not vow than that you vow and and not fulfill', in K. Dell \& W. Kynes (reds.), Reading ecclesiastes intertextually, pp. 28-41, fulfill, in K. Dell \& W. Kynes (reds.), Rear.
Bloomsbury Publishing Plc., London.

Liston, D.D., 1996, Joy: A phenomenological and aesthetic view. (Critical education and ethics), PhD dissertation, Dept. of Classical Languages and Literatures, The University of North Carolina, Greensboro, NC.

Loader, J., 1979, Polar structures in the book of Qohelet, Walter de Gruyter, Berlin.

Lohfink, N., 2003, Qoheleth. A continental commentary, transl. S. McEvenue, Fortress Press, Minneapolis, MN.

Lombaard, C., 2007, 'Of serpents, reeds, understanding, and turns: Some perspectives on implied apologetics and Pentateuch theory', Studia Historiae Ecclesiasticae XXXIII(1), 351-365.

Lombaard, C., 2012, 'Biblical spirituality, thematically approached: Methodological considerations around "discernment"', NGTT 53(3), 211-225, viewed 29 November 2016, from ngtt.journals.ac.za/pub/article/download/222/pdf

Lombaard, C., 2014, 'Mysticism and understanding: Murmurs of meaning (fulness) Unheard silences of Psalm 1', OTE 27(2), 472-488.

Lombaard, C., 2015, 'Biblical spirituality and transformation', In die Skriflig 49(2), Art. $£ 1950$.

Longman, T., 1998, The book of ecclesiastes, Wm. B. Eerdmans Publishing Co., Grand Rapids, MI.

Longman, T. III. \& Enns, P., 2008, Dictionary of the Old Testament: Wisdom, poetry \& writings: A compendium of contemporary biblical scholarship, Inter-Varsity Press, Nottingham.

Lorgunpai, S., 2006, 'The book of Ecclesiastes and Thai Buddhism', in R.S. Sugirthharajah (ed.), Voices from the margin: Interpreting the Bible in the world, pp. 347-354, (ed.), Voices from the
Orbis Books, New York.

Marcus, P., 2003, Ancient religious wisdom, spirituality, and psychoanalysis, Praeger Publishers, Westport, CT.

McCabe, R.V., 1996, 'The message of ecclesiastes', Detroit Baptist Seminary Journal 1 85-112.

McClymond, M.J., 1997, 'Spiritual perception in Jonathan Edwards', The Journal of Religion 77(2), 195-216. https://doi.org/10.1086/489969

McConville, J.G., 2013, 'Spiritual formation in the Psalms', in A.T. Lincoln J.G. McConville \& L.K. Pieterson (eds.), Exploratory essays in reading scripture spiritually, pp. 56-74, Wipf and Stock, Eugene, OR.

Medved, M., 1992, Hollywood vs. America: Popular culture and the war on traditional values, HarperCollins, New York.

Metz, J.B. \& Jossua, J., 1974, Theology of joy, Herder and Herder, New York.

Morgan, J.K., 2011, Living in the Tensions: Camus, Qohelet, and the confrontation with the Absurd, Liberty University, Lynchburg, VA.

Moschella, M.C., 2015, 'Calling and compassion: Elements of joy in lived practices of care', in M. Volf \& J.E. Crisp (eds.), Joy and human flourishing essays on theology, culture, and the good life, pp. 97-126, Fortress, Minneapolis, MN.

Murphy, R.E., 1955, 'Pensées of Coheleth', Catholic Biblical Quarterly 17(2), 304-314.

Murphy, R.E., 1992, Ecclesiastes. Word Biblical Commentary 23A, Word Books, Dallas, TX.

Murphy, R.E., 2002, The tree of life: An exploration of biblical wisdom literature, Wim B. Eerdmans, Grand Rapids, MI.

Nathan, E., 2014, 'Beyond the desert: Re-engaging the Bible today', in R. Beringer, R. Burggraeve, E. Nathan \& M. Steegen (reds.), Provoked to speech: Biblical hermeneutics as conversation, pp. 15-25, Peeters, Leuven.

Niemandt, C.J.P., 2016, 'Rediscovering joy in costly and radical discipleship in mission', HTS Teologiese Studies/Theological Studies 72(4), a3831. https://doi.org/10.4102/ hts.v72i4.3831

O'Brien, B.J., 2011, 'Can you imagine? Why imagination is crucial to the Christian life', ChristianityToday/ChristianBibleStudies.com, viewed 22 November 2016, from
http://www.christianitytoday.com/biblestudies/articles/theology/canyouimagine. http://

Oeming, M., 2006, Contemporary biblical hermeneutics: An introduction, Ashgate Publishing Ltd., London

Ogden, G., 1987, Qoheleth, JSOT, Sheffield.

Olivier, I.J., 2006, 'The strategic task of the church in creating spaces for spirituality', $\mathrm{PhD}$ thesis, Faculty of Theology, Northwest-University, Potchefstroom Campus.

Perdue, L.G., 2008, The sword and the stylus: An introduction to wisdom in the age of empires, William B Eerdmans Publishing Company, Grand Rapids, MI.

Peters, G., 2013, 'Spiritual theology. A historical view', in J. Goggin \& K. Strobel (eds.), Reading the Christian spiritual classics: A guide for evangelicals, pp. 79-94, Reading the Christian spiritual classics
InterVarsity Press, Downers Grove, IL.

Pigg, D.F., 2016, Qoheleth: Postcolonial Solomon. Introduction, Master of Sacred Theology thesis, Faculty of the School of Theology, University of the South, Tennessee viewed 22 November 2016, from https://dspace.sewanee.edu/handle/11005/3673

Provan, I., 2011, Ecclesiastes, songs of songs. The new NIV application commentary, Zondervan, Grand Rapids, MI.

Qohélet@FundacionQohelet, 2018, 'Felices de colaborar con Liter of Light México (Litro de Luz México)para llevarles capacitación de excelencia a través de \#CanDo', Twitter Post, 18 April, viewed 27 May 2018, from https://free.facebook.com/ FundacionQohelet/?_tn__=C-R\&_rdc $=2 \& \_r d r$
Qoheleth Osb, 2018. Let us pray for the end of taking lives, post, 24 May 2018, viewed 15 November 2016, from https://web.facebook.com/Qoh\%C3\%A9let-26988 $1882194 /$

Rahner, K. 1984, Foundations of Christian faith: An introduction to the idea of Christianity, Crossroad, New York.

Redding, J., 2013, 'Excess and moderation in Qohelet: An economic ideology', Journa of Ecumenical Studies 43(3), 370-382, viewed 01 November 2016, from http:// s3.amazonaws.com/academia.edu.documents/34281986/Redding Qohelet Excess and Moderation.pdf?AWSAccessKeyld=AKIAJ56TQJRTWSMTNPEA\&Expir es $=14 \overline{7} 887 \overline{5} 029 \&$ Signature $=$ mcd9oLVVb03O6MOoUuFNDy79MF8\%3D\& respon se-content-disposition=inline $\% 3 \mathrm{~B} \% 20$ filename $\% 3$ DExcess and Moderation in Qohelet_An_Econ.pdf

Roberts, C.R., 2013, Emotions in the moral life, Cambridge University Press, Cambridge.

Roberts, L., 2006, 'Shifting the lens on organizational life: The added value of positive scholarship', Academy of Management Review 31(2), 292-305. https://doi. org/10.5465/amr.2006.20208681

Robbins, V.K., 1996, Exploring the texture of texts: A guide to socio-rhetorical interpretations, Trinity Press International, Harrisburg, Pennsylvania, PA.

Ryken, P.G., 2010, Why everything matters, Crossway, Wheaton, IL.

Rudman, D., 2001, Determinism in the book of Ecclesiastes, Sheffield Academic Press, Sheffield.

Sabo, E., 2013, 'Reading and writing Qohelet: Reflections on the heart, pleasure, and death', M.A. thesis, Department of Religious Studies, University of Alberta, University of Alberta, Edmonton, Canada.

Schultz, R.L., 2015, 'Qoheleth and Isaiah in dialogue', in K. Dell \& W. Kynes (eds.), Reading ecclesiastes intertextually, pp. 57-70, Bloomsbury Publishing Plc., London.

Sekine, S., 1999, Transcendency and symbols in the Old Testament. A genealogy of the hermeneutical experiences, Walter de Gruyter, Berlin.

Senapatiratne, T., 2014, 'A citation analysis of Ecclesiastes scholarship: A test case using citation analysis in biblical studies', Advances in the Study of Information and using citation analysis in biblical studies', Advances in the Study
Religion 4, Article 2. https://doi.org/10.21038/asir.2014.0001

Seow, C., 1996, 'The socioeconomic context of "The Preacher's" hermeneutic (page 168)', The Princeton Seminary Bulletin 17(2), 171-189.

Seow, C., 1997, Ecclesiastes: A new translation with introduction and commentary, Doubleday Anchor, New York.

Sharp, C.J., 2009, Irony and meaning in the Hebrew Bible, Indiana University Press, Bloomington, IN.

Sneed, M.R., 2012, The politics of pessimism in ecclesiastes. A social-science perspective, Society of Biblical Literature, Atlanta, GA

Soliman, F., Sturgeon, G. \& Hargest, R., 2015, 'Revisiting an ancient treatment for transphincteric fistula-in-ano "There is nothing new under the sun" Ecclesiastes $1 \mathrm{vg}$, Journal of the Royal Society of Medicine 108(12), 482-489. https://doi. org/10.1177/0141076815588322

Steenkamp, A., 2010, 'Power hour with CANSA', Madibeng Times, 19 November, viewed 27 May 2018, from http://madibengtimes.co.za/wp-content/uploads/2015/06/ Thursday-18-November-2010.pdf

Steenkamp, A., 2011, 'Roses tea for volunteers', Kormorant 14(6), 9.

Steenkamp-Nel, A., 2018a, 'Shifting landscapes: Spirituality in the life of the African healthcare volunteer', in A. de la Porte, N. Joubert \& A. Oberholzer (eds.), Proceedings of the 2nd Biennial South African Conference on Spirituality and Healthcare, pp. 261-277, Cambridge Scholars Publishing, Newcastle.

Steenkamp-Nel, A.E., 2018b, 'African spirituality and transformation: Fragments and fractures of the shifting sacred', HTS Teologiese Studies/Theological Studies 74(3), 4941. https://doi.org/10.4102/hts.v74i3.4941

Tanner, B.L., 2001, The book of Psalms through the lense of Intertexuality, Peter Lang, New York.

Tene, O. \& Polonetsky, J., 2013, 'Big data for all: Privacy and user control in the age of analytics', Northwestern Journal of Technology and Intellectual Property 11(5), 239-273.

Thiselton, A.C., 1992, New horizons in hermeneutics, Zondervan, Grand Rapids, MI.

Thompson, I.M., Lucia, M.S. \& Tangen, C.M., 2007, 'Commentary: The ubiquity of prostate cancer: Echoes of the past, implications for the present', International Journal of Epidemiology 36, 287-289. https://doi.org/10.1093/ije/dym056

Waaijman, K., 2000, Spiritualiteit: Vormen, grondslagen, methoden, Uitgeverij Kok, Kampen.

Waaijman, K., 2002, Spirituality: Forms, foundations, structures, Peeters, Leuven.

Waaijman, K., 2006, 'Conformity in Christ', Acta Theologica 27(8), 41-53. https://doi. org/10.2143/SIS.17.0.2024643

Waaijman, K., 2007, 'Spirituality - A multifaceted phenomenon. Interdisciplinary explorations', Studies in Spirituality 17, 1-113.

Weeks, S., 2011, Ecclesiastes and scepticism, T\&T Clark International, New York.

Whitehead, A.N., 1929, Process and reality, The MacMillian Company, New York.

Whybray, R.N., 1982, 'Qoheleth, preacher of joy', Journal for the Study of the Old Testament 7, 87-98. https://doi.org/10.1177/030908928200702305

Yale Center for Faith and Culture, 2016, Joy among the virtues, actions, and emotions, Yale University, viewed 18 November 2016, from http://faith.yale.edu/joy/ virtues. 